\title{
Analysis of the Sector Vegetables of Niamey: Social Dimension of Rapidly Growing Activities \\ Hassoumi DJIBO
}

Boubacar BA University of Tillabéri, Niger

"Corresponding author: Hassoumi DJIBO, Doctor in socio-economics of development, Assistant Professor, Research Professor at Boubacar BA University of Tillabéri, Niger, Tel: 92080683; E-mail: dhassoumi@yahoo.fr

Rec Date: August 29, 2018; Acc Date: September 17, 2018; Pub Date: September 22, 2018

Copyright: @ 2019, Hassoumi DJIBO. This is an open-access article distributed under the terms of the Creative Commons Attribution License, which permits unrestricted use, distribution, and reproduction in any medium, provided the original author and source are credited.

\begin{abstract}
A sector is a chain of production and marketing of a raw agricultural product. It evolves in time and space. As part of this study, we will demonstrate the social role of the fruit and vegetable sector. The main hypothesis of our study consists in supposing that the actors of the sector are vulnerable people who have no other opportunity. The respondent concerned 428 people from two departments (Kollo of Baleyara) and the city of Niamey. The results reveal that the actors of the sector vary according to the locality. Unlike in urban areas where the production of vegetables is dominated by men, in the countryside it is carried out by women. The marketing of fruit and vegetables does not require large financial means and attracts mainly national immigrants.
\end{abstract}

Keywords: Spinneret; Vegetables; Sellers; Niamey

\section{Introduction}

A vegetable sector is a succession of economic activities that include actors with reciprocal relations to produce and market a raw agricultural product. Input suppliers, producers and traders develop strategies based on the supply of this product. The sector studied in this document is composed of activities, the authors of which are generally lower-income persons. It can be considered as part of the popular economy, defined as: the set of economic activities and social practices developed by the popular groups to ensure, through the use of their own labor power and resources available, the satisfaction of basic needs, both material and immaterial. Thus, by bringing the sector closer to this classical branch of economics, it will be seen that at each level of the chain the actors are able to meet their basic needs and to share the gain with other members of the family which leads us to deal only with the social aspect of the sector.

\section{Problematic}

Global production of fresh and processed fruits and vegetables is in the order of one billion tones and has more than doubled in three decades. Asia accounts for $54 \%$ of the world supply. Trade has increased fourfold and is at the level of 75 million tones. Arrive at the head of these exchanges, tomatoes and dried onions for vegetables, bananas for fruits [1]. Market gardening has experienced a boom in Burkina Faso during the last thirty years, though marked by successive droughts. The area devoted to vegetable and fruit crops with about 8,000 ha for market gardening and 22,000 ha for fruit growing [2].

Niger can take advantage of its geographical location with the Maghreb to carry out fruitful commercial exchanges in order to stimulate its economy and improve its rank in the world ranking of the less advanced states. Yet, the country is still one of the poorest in the world with a ratio of the poor population that is about $48.9 \%$ compared to the national poverty line (US \$ 1 per day) and a farm labor force around $87 \%$. It should be noted that the share of agriculture in GDP is 37 percent. It has become an essential economic and social sector which is of vital importance to promote in this developing country [3]. It should be noted that annual vegetable production is difficult to estimate and markets are heavily flooded with fresh produce from other countries in Africa, Europe and even Asia. Accessibility and availability of food have been favored by the liberalization of the agricultural sector and the government policy put in place by 2021 . The implementation of this policy has only been possible through the funding provided by the technical and financial partners and the commitment of rural people who now have their own agricultural and food policies. This policy and institutional framework on agriculture and food facilitated the development of the sector throughout the country.

\section{Materials and Methods}

\section{Presentation of the study environment}

The city of Niamey, capital of the Republic of Niger, was built on both sides of the Niger River, for a length of about $15 \mathrm{~km}$. The left bank is the part where about $86 \%$ of its population is concentrated $(1,192,979$ in habitants). Its accelerated urbanization has a-negative impact resulting in a sharp decline in agricultural land. As a result, market gardening is mostly developed along the other side $\left(5^{\text {th }}\right.$ district municipal). Niamey extends over $700 \mathrm{~km}^{2}$ between $13^{\circ} 20^{\prime}$ and $13^{\circ} 35^{\prime}$ north latitude and $2^{\circ} 20^{\prime}$ and $13^{\circ} 35^{\prime}$ east longitude. It is bounded on the north by the rural commune of Karma, we the north-east by Hamdilahi, we the east by the rural commune of Libore and we the South by the rural commune of Bitincodj. Niamey is subdivided into five municipal districts, four of which are on the left bank of the river. It should be recalled that the last census shows that the population of Niamey has reached 1,388,682 inhabitants [4] and the bulk of services and commercial activities are concentrated on the left bank which holds twenty-six out of total of twenty-seven) markets. The supply of fruits and vegetables necessarily passes through the markets distributed in the different neighborhoods of the city. 


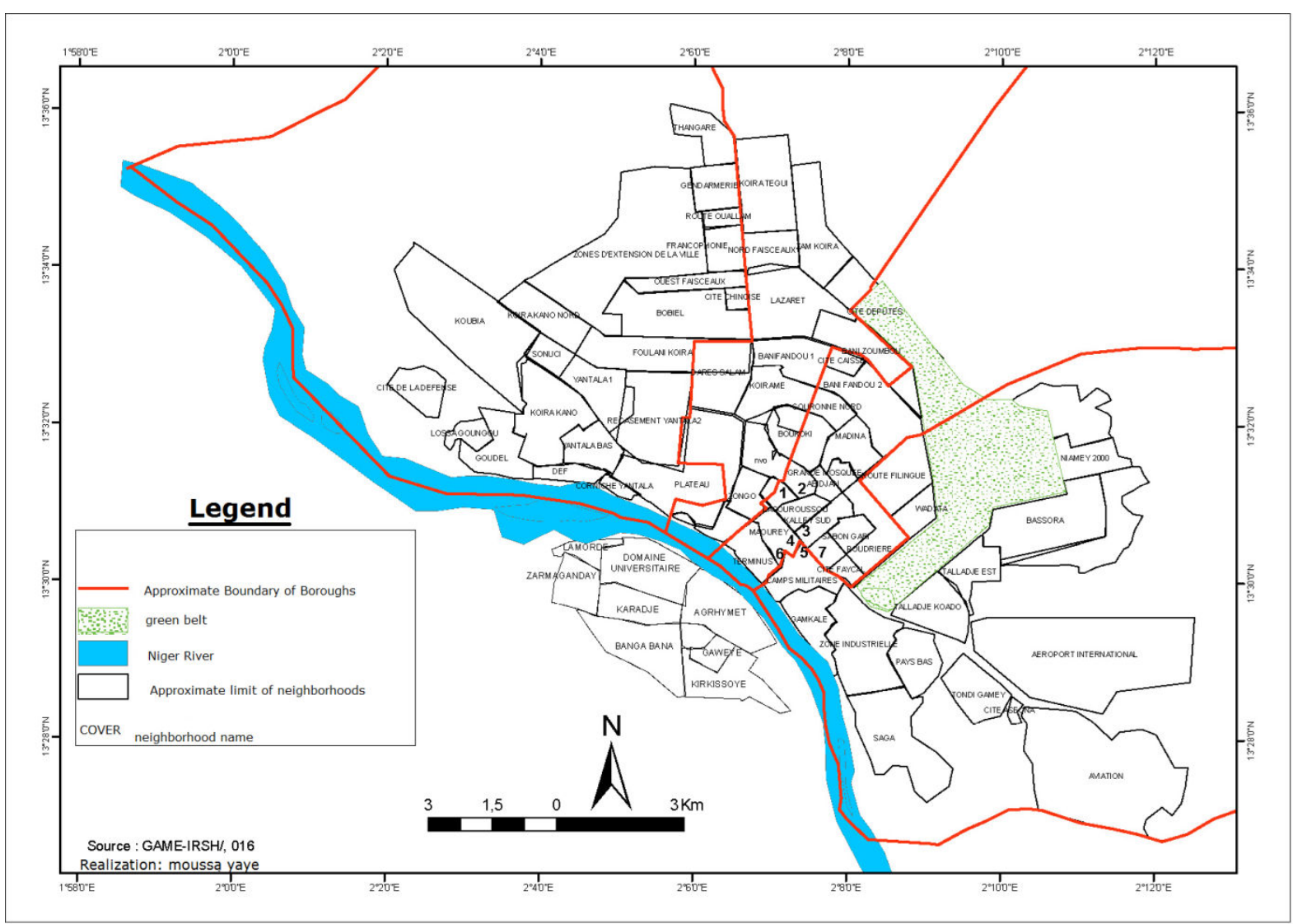

Figure 1: Map of Niamey.

This study was carried out in a comprehensive approach that consists in understanding by interpretation the meaning that actors in the sector give to their actions. These actors are then taken individually. This approach required a fine observation of the various activities that make up the sector. However, it was supplemented by a survey in which a questionnaire was sent to the various actors (producers, resellers and restaurateurs). The study involved a random sample of 428 people, including 338 female producers distributed between the Balleyara department and Kollo, 30 producers and 60 dealers in the city of Niamey (Figure 1). Indicators that have facilitated work are per capita Gross National Income (GNI) and the poverty line. These indicators are compared to the incomes perceived by the actors. This allowed us to measure the contribution of each of these activities in improving their living conditions. Variables such as origin, marital status, age, sex and date of installation in the market were included in the questionnaire. This study was conducted over a two-year period (2016-2018). Vegetable production is studied during the normal period (from November to January) and in the off-season (March-September) during which production decreases. Each of these periods has been studied doubly. The administration and processing of data was done by the Sphinx software and sometimes through the use of Excel. The Survey was conducted throughout the season.

\section{Results}

The vegetable sector is a succession of economic activities containing individuals who are fully involved and who develop their own strategies to achieve the objectives set. At first glance, there are producers whose strategy to develop is to reduce production costs in order to make the most profit. It happens that this desire to produce with the least cost comes up against other realities that require huge investments (Appearance of insects or locust's pests, drought etc). These costs vary over time (Variable costs) and regardless of the size of the constraints; vegetable production provides farmers with a significant added value.

In urban areas of Niger (especially in Niamey), vegetable production is dominated by men. This male hand on the sector is linked to the high cost of living and the scarcity of arable land. This is encouraged by the appetite for urban land and is a major obstacle to the development of market gardening. Each family wants to get their own house, leading to high speculation and land casualization. Seasonal production is divided between self-consumption and sales. The first part (selfconsumption) is intended to take care of the family in fresh products. As for the second, that is to say the marketing, it guarantees the support in food, clothing and housing for the producers living in a city where the price of the necessities of necessity does not cease climbing. It should also be remembered that producers receive regular income to buy food and play a social role by contributing to marriage ceremonies and baptism in society [5]. Given the wide range of kinship ties, driven by intense socialization, polygamy, family recomposition and adoption, producers share vegetables with others. For, giving is a very important social act in social representations. Money raised in market gardening becomes a means of social integration and assertiveness in a changing 
Page 3 of 5

society and where life becomes more and more difficult. As a result, the activity guarantees financial autonomy for vulnerable people.

In the Niger countryside, market gardening is dominated by widows and married women, most of whom have their spouses on the run. It must be remembered that women producers organize themselves into a cooperative, commonly referred to as a group (Table 1). This framework serves as a place of sharing and mutual aid. It is created either by kinship or affinities that market gardeners share with each other. It can already be said that production takes place in a convivial environment. Thus, the quantity produced is shared among the members of the peasant organization. This production is most often marketed in Niamey. In order to facilitate the sale, women exchange information on the market (price variation). The income they receive not only allows them to buy home decorating materials for parties, clothes, but also to save money to meet the expenses of their children's wedding. Producers often take care of the family (during the exodus of their husbands). The reason for women's involvement in the sector is also related to the nutritional and nutritional role that market gardening plays in the household [6]. A UNDP report points out that there is a precariousness of food security in rural Africa [7]. According to the author, the contribution of fruits and vegetables to food security can be assessed at two levels: the intake of nutritional elements considered essential for a balanced diet and the diversification of the incomes of the populations which allows these to acquire basic food products and play their full role in society.

\begin{tabular}{|l|l|l|l|l|}
\hline Village & Group & $\begin{array}{l}\text { Number of } \\
\text { members }\end{array}$ & $\begin{array}{l}\text { Existing } \\
\text { website }\end{array}$ & Agreement \\
\hline \multicolumn{5}{|l|}{ Ballayra Department } \\
\hline $\begin{array}{l}\text { Djoungo } \\
\text { Fandou }\end{array}$ & Moribane & 150 women & 1 ha & $012 / \mathrm{CRT} / 2013$ \\
\hline Firguine & Koyguina & 52 women & $1.5 \mathrm{ha}$ & $024 / \mathrm{CRT} / 08$ \\
\hline Kabey & Zadayan & 54 women & $1.5 \mathrm{ha}$ & $55 / \mathrm{CRT} / 07$ \\
\hline
\end{tabular}

\begin{tabular}{|l|l|l|l|l|}
\hline Sandiré & Alhéri & 30 women & 2.5 ha & 049/CRT/2009 \\
\hline \multicolumn{4}{|l|}{ Department of Kollo } \\
\hline Sorey & $\begin{array}{l}\text { Farhan } \\
\text { sorey } \\
\text { harey }\end{array}$ & 32 women & 1.5 ha & $834 /$ AK \\
\hline $\begin{array}{l}\text { Gonzari } \\
\text { Béri }\end{array}$ & Sougui & 20 women & 2 ha & 995/AK \\
\hline
\end{tabular}

Table 1: Distribution of farmers' organizations.

The results of our study reveal that the marketing of vegetables is carried out in the different local markets (Katako, big market, Djamadje, Harobanda, Dar Salam and Bonferey), on the main highways and sometimes in the districts. The concentration of sellers is felt in the markets of downtown (Djamadje and Dar Salam) with a strong clientele. The vegetable trade is dominated by a high proportion of women. These play a decisive role in its development. The market of Djamadjé (swallow in local language) is the most popular. This is due to its location in relation to the city Centre. His animation is almost permanent. The social status of the vendors is divided between widow, divorced and married woman whose husband is in a situation of poverty. These women participate in one way or another in the care of their family.

Men are also engaged in the vegetable trade. They practice the activity in the local markets (photo 1), on the boulevards and in neighborhood shops. Regarding the first category, there are retailers and semi-wholesalers. The latter have significant financial means and make fairly high daily profits (5,000 to 10,000 FCFA). Our study reveals that the year of installation of vendors in the markets is approximately seven years. Given their seniority in and their time spent on the activity, they manage to get houses in the capital 


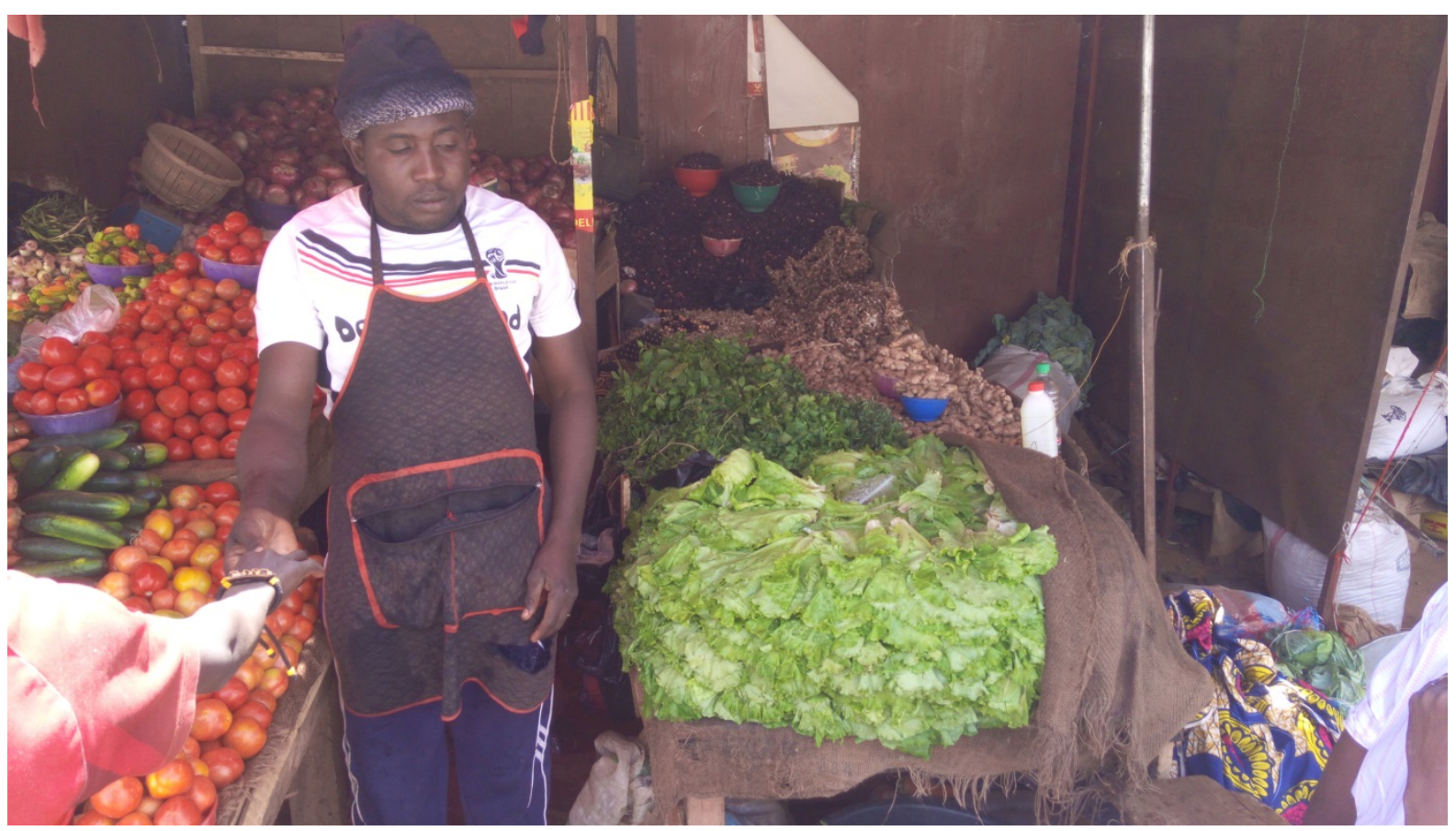

Figure 2: Vegetable seller.

The vegetable trade creates a ripple effect for young people in exodus, that is to say the fact that one economic activity practiced by one person attracts in another, either by affinity or family affiliation. Inside the training effect there is also mimicry. The training effect is created through the good information received on an activity. This is the reason why we find that the sellers are mainly from the same department (Department of Doutchi). There are also people from other parts of the country who first start learning from a parent before becoming vegetable sellers (Figures 2 and 3). They become so, walking merchants. These are immigrants who have no other opportunity. They still manage to take care of themselves and send money to their families. The proportion of street vendors is around $16.62 \%$. It should be noted that a street vendor's life is like that of a talibé and a street child who walks all day long. The strategy of a mobile reseller is focused solely on savings. It must be remembered that there are vendors who prefer to install their stand on the main roads of the city of Niamey. They form family micro-enterprises of two to three people. The youngest takes care of the transport and the entrepreneur is assisted by another member of the family (usually brothers) who replaces him when the need arises. The sale of vegetables is a purveyor activity that regularly provides significant income.

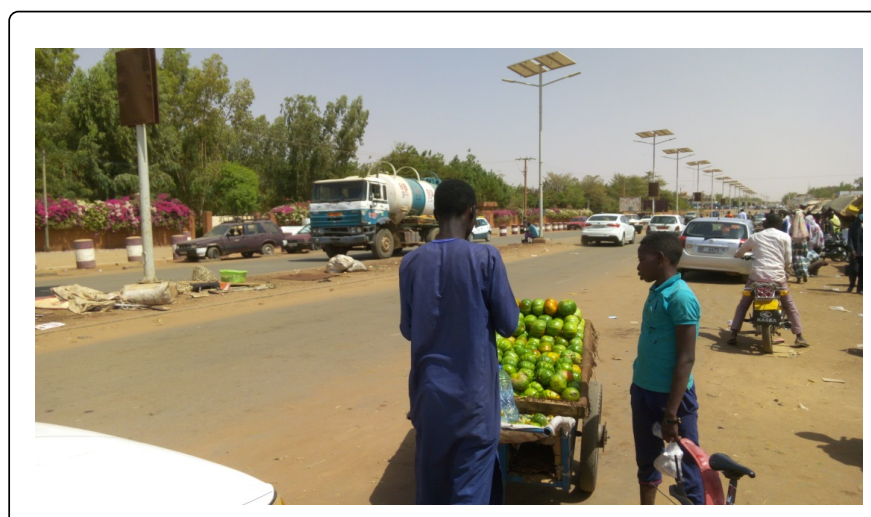

Figure 3: Seller travelling.

\section{Discussion}

It should be noted that the method of marketing vegetables varies in time and space. In the city of Niamey, vegetables are sold in markets, on major roads, and sometimes in neighborhoods. In Europe for example (Especially in France), vegetables are marketed through grocery stores, weekly markets, shopping centers and the Internet [8]. The same goes for sellers who vary according to the economic structure and infrastructure of the country. In Niamey, for example, lower income sellers account for up to $16.62 \%$, while in France the sale of vegetables creates jobs and generates considerable resources for the benefit of the State. Unlike the study [9], this shows in his doctoral thesis that the production of vegetables is carried out in Aquitaine (France) by homogeneous companies with large financial means. As 
for our study, it reveals that in Niger, vegetables are produced by family businesses and sometimes by women farmers' organizations.

It should be noted that the results of our study are similar to those [10] who indicate that vegetable production is often carried out by farmers' organizations. This is quite normal, when we know that the characteristics of market gardeners as well as those of socio-economic structures are identical in these two countries which are all landlocked and which are located in the Sahelian band south of the Sahara. Niger and Burkina Faso then undergo the same climatic, ecological and economic constraints. The results of the author deviate from our study on marketing. For, the author demonstrates in his master thesis that all productions are sold to intermediaries. This is explained by the involvement and importance that traders give to the vegetable sector. Our results also differ from those of the study carried out [11] which shows that the marketing is done in the packing stations, the storage magazines, at the station and in the markets. However, with regard to the categories of salespeople, there are common points between the studies [12]. For both Niamey and Bamako, there are women sellers, wholesalers and semi-wholesalers in the vegetable sector who make market gardening a way to fight against food insecurity and poverty. This allows us to say that the vegetable sector plays a role in these two cities in integrating the households that are involved.

\section{Conclusion}

The conclusion of this article makes it possible to say that the vegetable sector plays an important role of social integration. It allows some women to occupy the position of head of the family in society. This is the case of widows, divorced and women whose husbands do not have enough financial means to support the family. The market gardening actors vary according to the locality. Although it is dominated in rural areas by women, in urban areas it is practiced mainly by men. This variation of actors is accompanied by the variation of the mode of supply in time and in space. The vegetable sector of Niamey reflects the socio-economic realities of the country. Because, it is different from that of Mali and Burkina Faso, even if there are some common points.

\section{Conflicts of Interest}

There are no conflicts.

\section{References}

1. Françoise F (1999) Production and world trade, CIRAD editions, France.

2. Policy Analysis Cell (2007) DSA/DGPSA/MAHRH, FAO policy assistance support service, Burkina Faso.

3. Illiassou MM (2005) Collective management of irrigated systems: The case of rice irrigation schemes in the Niger River Valley in Niger, Université de Toulouse-le Mirail, France.

4. Directorate of Statistics and National Accounts (2013) General census of population and housing ministry of population, Niger.

5. Hassoumi D (2017) Moringa oleifera, a tool for local development: the case of the rural commune of Liboré. Journal of Multidisciplinary Studies in Economic and Social Sciences pp: 55-68.

6. L Andres, P Lebailly (2011) Peri-urban agriculture: Market gardening in Niamey, EHESS, France.

7. Temple L (2001) Quantification of productions and exchanges of fruits and vegetables in Cameroon. Cahiers Agricultures 10: 87-94.

8. GESRA (2014) Optimizing the supply of fruits and vegetables in social and solidarity grocery stores, Practical Guide, France.

9. Naves P (2017) Cost, local! A sociology of the government of the fruits and vegetables sector, University of Bordeaux, France.

10. Bertrand R (2009) The economic performance of market gardeners in Burkina Faso: Linear regression, 2IE, Burkina Faso.

11. Thiam AM, Fofana HM, Sidibe A (2001) Capitalization study of information on the fruits and vegetables sector. Ministry of Rural Development, West Africa.

12. Castel O (2007) From the informal economy to the popular solidarity economy: Concepts and practices, University of Rennes, France. 